Manuel Joao Ramos

Isabel Boavida

\title{
Ambiguous Legitimacy: the Legend of the Queen of Sheba in Popular Ethiopian Painting
}

In: Annales d'Ethiopie. Volume 21, année 2005. pp. 85-92.

Citer ce document / Cite this document :

Joao Ramos Manuel, Boavida Isabel. Ambiguous Legitimacy: the Legend of the Queen of Sheba in Popular Ethiopian Painting. In: Annales d'Ethiopie. Volume 21, année 2005. pp. 85-92.

doi : 10.3406/ethio.2005.1094

http://www.persee.fr/web/revues/home/prescript/article/ethio_0066-2127_2005_num_21_1_1094 
Annales d'Éthiopie, 2005, vol. XXI: 85-92

\title{
AMBIGUOUS LEGITIMACY: The Legend of the Queen of Sheba in Popular Ethiopian Painting ${ }^{1}$
}

\author{
Isabel Boavida 2, Manuel João Ramos ${ }^{3}$
}

Traditional Ethiopian Christian art is a genre born and bred under the stylistic and structural conditionings of traditional religious painting. But, to a great extent, it survived and developed thanks to the fact that, for over a century now, Western expatriates and tourists have been interested in buying it. Such paintings are generally thought of as a "folk" and "naï" in that they continually repeat the same historical or ethnographic themes in a very conventional way.

An important feature of these paintings is the fact that they are composed of a series of rectangles organized in strips and thought of as "stories" that usually share a number of codifying elements. Like the fidël - the syllabic writing of Abyssinian languages-, they usually "read" from left to right and from top to bottom. They use the same visual grammar as the painted frescos of Ethiopian Orthodox churches: i.e., the use of a limited range of bright and flat colours, the drawing of black lines as contours of the figures, the opposition between beneficial characters represented as full-faced and malignant ones represented in profile, the stress on exaggerated eyes, etc. Only very seldom are they influenced by representational techniques of Western provenance designed to create illusions of perspective and tri-dimensionality.

Primary, and ever recurring, examples of this genre are the paintings depicting the legend of the Queen of Sheba and her visit to the Israeli king Solomon. This story, including her union to the king, the conception of their son Mënilëk and the latter's coronation as king of kings of Ethiopia, is frequently preceded by an apparently unrelated episode. Indeed, the first (upper) strip of these paintings generally deals with the slaying of Arwe, the Prince Serpent, and the rise of the outsider Agabos, who is identified as the father of Makeda (or Azeb), the Queen of Sheba ${ }^{4}$.

The most detailed versions of the painting tell the following tale:

1. Illustrations for this article can be found in $C D$ at the end of this volume.

2. Centro de Estudos Africanos - Faculdade de Letras, Universidade de Lisboa.

3. Departamento de Antropologia - Instituto Superior de Ciências do Trabalho e Empresa, Lisboa.

4. Azeb is the local name, taken from the cardinal point, given to the Queen of the South mentioned in the Ancient Testament and perceived as the Queen of Ethiopia. This corresponds to the claim, in a Christian context, for an Ethiopian Sheba. 
Arwe, an insatiable giant serpent, is born from the waters of the river where a woman washed herself after sleeping with her lover. The serpent becomes the ruler of the country and demands a regular tribute from his subjects. A man named Agabos offers to end this serfdom and feeds poison to a goat destined for Arwe. The serpent eats the goat and dies. Agabos is crowned king. Sometime after, he dies and his daughter, Makeda or Azeb, succeeds him.

A travelling merchant (his clothes identify him as an Arab) who returns to Ethiopia from Jerusalem refers the name and wisdom of Solomon to the queen. She decides to travel to Jerusalem and meet the wise king. He teaches her the manners and secrets of royalty, and wishes to sleep with her. She refuses and Solomon forbids her from taking any goods from his palace lest she bows to his sexual demands. He offers her spicy food and, at night, her servant first and she afterwards, both drink from water jug (conveniently placed by the beds) and are thus forced sleeping with Solomon: "What good, he says, is more precious than water?"

The queen wishes to return to Ethiopia and Solomon offers her a ring (or a portrait) so that he may recognize his son in case she bears him one. The queen and the servant give birth to a pair of (almost) identical twin half-brothers who, when they grow, also travel to Jerusalem to meet their father.

Solomon recognizes his sons and wishes that they stay in Israel, for Mënilëk (Makeda's soon) is supposed to succeed his father as king. They decide nevertheless to return to Ethiopia. Solomon decides that the firstborn sons of Israel should travel with Mënilëk and found an Israelite kingdom in Ethiopia. To the fury of the king, the party secretly remove the Ark of the Covenant from the Temple and take it to Ethiopia. At their arrival, Makeda resigns and Mënilëk is crowned as "king of Judah" in Aksum.

Whereas the legend of the Queen of Sheba is well known in a variety of national and regional versions throughout the Middle East, the peculiarity of the Ethiopian development of the story must be stressed (see below). Also, a curious effect of cultural and imagistic feedback seems to have been at work in the sedimentation of the Ethiopian pictorial tradition regarding the Queen of Sheba, in the 20th century. The appearance, in the late 19th century, of various translations and adaptations from Arabic, Jewish and Persian literary traditions renewed the Europeans' interest in the story of Solomon and Sheba and paved the way for the first published translations of the Këbrä Nägäst, or "Glory of the Kings" ' - a medieval book where a courtly version of the Ethiopian legend of Makeda and Solomon is presented. For their non-erudite English translation of this text ${ }^{2}$, in 1907, Hughes le Roux and J. Van Horst

1. Bezold, Carl, Kebra Nagast, die Herrlichkeit der König, München: 1905; Le Roux, Hugues, Chez la Reine de Saba, chronique éthiopienne, Paris: 1914; Budge, Ernest A. Wallis, The Queen of Sheba and her only Son Menyelek, London: 1922.

2. Magda, Queen of Sheba. From the ancient royal Abyssinian manuscript, "The Glory of the Kings" [Këbrä Nägäst]. Now first translated into English from the French of $M$. Le Roux by Mrs. J. Van Vorst, with an introduction by Hugues Le Roux. Illustrated by Michel Engueda Work, an Abyssinian artist. New York and London, 1907. Later, Hughes Le Roux included the same legend in his travel book, Chez la reine de Saba, Paris, 1914. (See Tubiana, 2001). 
commissioned a number of illustrations of the legend from the Ethiopian artist Mika'el Engeda Worq. This commission, and this translation, had the probable effect of helping promote a specific folk painting market for Westerners in the Ethiopian capital, which was already well in place by the late nineteen twenties, when Marcel Griaule acquired the painting he reproduces and presents in his short article "La légende illustrée de la reine de Saba" '. Griaule suggests that the Sheba paintings could be seen in affluent Ethiopian families' homes at the time of his stay in Ethiopia, in the late twenties. But the fact remains that the production of these and other folk paintings have been, throughout the 20th century, inextricably connected to the Western presence in Ethiopia.

Painters like Woldu Habta Mika'el (b. 1939), Balatschaw Yimer (ca. 18941957), Afewarq Mengescha (b. 1944), Getachew Gebre-Hiwot Kebede (b. 1949) or Jambere Hailu (1913-1994), some of whom had a religious education and were reputed church painters, dedicated a great deal of their art to the (re)creation of iconographic motives and scenes for the "traditional" or "folk" art market ${ }^{2}$. To make their work easily recognizable as such, they developed an aesthetic based on repetition of forms and of narrative processes. The medium used (cotton canvas, parchment, sometimes paper) and their dimensions made (makes) them very easily transportable by the foreign visitors and expatriates with an interest in the Ethiopian traditional art market. ${ }^{3}$

Two rather different literary traditions have come together in these paintings, as already hinted above: the ones concerning the monster serpent Arwe, and the ones referring to the Queen of Sheba, Solomon and the Ark of the Covenant. As for the story of the slaying of Arwe, of which at least 10 major variants are known, ${ }^{4}$ it is connected to the idea of political change via the institution of a new dynasty, but also to the Christianization of the country (in some versions, Arwe is killed by the 9 saints that bring Christianity to Ethiopia) and to the creation of a grain that has became staple food in Northern Ethiopia (the cereal known as $t^{\prime}$ eff). It is mostly a popular oral legend told by peasants from the Amhara and Tëgray regions with many local variations, such as the founding stories of many churches and convents, where Arwe dies at the hands of the church saint(s) and paganism is eradicated (see, for instance, the founding legend of Këbrän Gabrë'el's church in lake T'ana) - an iconographic theme that

1. Griaule refers that, while he acquired his painting from a young painter living in Addis Ababa, the legend and its painted version were familiar to painters all over Abyssinia. But he adds that older masters refused to do such paintings, arguing that they "weren't used to that kind of work" (Griaule, 1930: 10).

2. An art market sometimes derogatorily called "airport art".

3. A market that almost died out during the communist military regime known as the d'erg. 4. Arwe has a twin sister, Azeb, who burns him to death, in others Agabos, poisons Arwe and either marries Azeb or is the father or grandfather of Makeda = Azeb; in others still the nine saints combat and kill the serpent with prayers and signs of the Cross. Perret and Denais (Perret \& Denais, 1983: 139-50) offer a brief comparative analysis of the story. The reason why only the painted versions of the story portray the killing of Arwe as an act of poisoning could not be established (Perret \& Denais, 1983: 146). 
echoes that, also very popular in Ethiopia, of Këdusse Giorgis (St. George) slaying the dragon (fig. 1).

One may reasonably suspect that the story of Arwe refers to a major literary theme in the Ancient World: that of the slaying of the serpent-dragon. There are also sufficient hints of its connection to a pan-African cosmological mythical theme, namely that of the Rainbow Serpent, where a water python snake with clear functional and symbolic similarities with Arwe is killed either to ensure the restoring of order in the physical world or as a consequence of a dynastic change in the political system of a specific society (Heusch, 1982: 33175). Inevitably, a third layer of interpretation of the Arwe myth comes from Judeo-Christian literature and theology. But the richness of the myth defies simple analogies between Arwe and the notion of the Serpent-Devil. Indeed, an important element should be taken into consideration: unlike that demonic figure, Arwe is not poisonous to humans but rather is itself poisoned by a man who subsequently becomes king - or, in some versions, its mother is "infected" with human semen floating in the waters of a river it crossed and gives birth to Arwe and to Azeb, her human twin sister who finally lets it burn to death (see Perret \& Denais, 1983: 133). Hence, Arwe is an ambiguous figure - malignant, yes, but incorporating a positive aspect (from its burned head flourishes a beneficial cereal grain) 1 - that mirrors an equally ambivalent view of political power (fig. 2).

Makeda-Azeb is the obvious link connecting both literary traditions. In the painted stories, she appears quite consistently as the daughter of the Serpentslayer Agabos and, regardless of some interesting differences in style and content, there is little or no overall variation in the choice of frames, figures and sequences adopted by most Ethiopian traditional painters to tell the stories of Arwe and of the Queen's encounter with Solomon and the begetting of her habasha ${ }^{2}$ son Mënilëk.

At a first glance, the second literary tradition from which the paintings draw their subject matter seems to refer solely to the Abyssinian "official" version of the biblical report on the encounter, which was crystallised in the Këbrä Nägäst or "Glory of the Kings" - the founding myth of the Shäwan native dynasty that ruled Ethiopia for seven hundred years (ca. 1270-1974). But it must be stressed that some characterizing elements of the painted stories are totally absent from the medieval text (see below).

The complex tale of the medieval text brings together two Old Testament themes: the visit of Queen of Sheba to King Solomon of Israel, and the loss of the Ark of the Covenant. Although it reads as a somewhat haphazard compilation of different texts, the Këbrä Nägäst deals mainly with the origin and coronation of Mënilëk, the mythical founder of the Solomonid kings of Ethiopia,

1. See the well-known Ethiopian legend where Arwe helps the saint Abuna Aregaye reaching the top of the convent of Däbrä Dämo, in Tëgray, and the numerous references of giant snakes living underneath churches and convents, in Northern Ethiopia.

2. Amharic: "of mixed blood" (of probable Arabic origin); Portuguese: abexim, hence Abyssinian. 
and evolves around the concept of the "covenant" - between God and the ancient patriarchs, God and the Solomonids, and finally between God and all Mankind through the sacrifice of Jesus Christ. The tale emphasises the emergence of a new identity for Ethiopians' as God's elected people- the token of which is the Ark stolen by Mënilëk and his companions with the blessing of Këdusse Mika'el (the Archangel Michael).

The Ancient Testament's theme of the encounter between the Queen of Sheba and Solomon has produced a variety of tales spreading from the Middle East to Northeast and North Africa and even to Europe. The Abyssinian version not only stresses the idea of racial miscegenation (or "semitization") as a major trait of the cultural identity of Northern Ethiopians, but also reinterprets the theme both in political and theological terms. As the founding myth of an usurping dynasty, it may be read as a self-legitimizing stance that adroitly manipulates two biblical discursive models to justify the Solomonid's power: the Prophecy and the Chronicle'. And, because the Këbrä Nägäst yields an implicit didactic intention, the underlying lesson is about the nature of power and its legitimacy.

Indeed, from its inception, the story of Sheba and Solomon is concerned with the problem of legitimacy. In the Bible, the queen travels to Jerusalem to offer gold for the Temple and to test the king's wisdom, only to finally recognize that Solomon's power and wisdom derives from the true God of Israel. The enigmatic concision of the biblical episode has sparked a millenary flow of stories that develop this matrix in many different directions. Ironically, the answers they offered to the original enigmas only seemed to have thickened the mystery. The tester of Solomon became herself tested. The long search for her origin and identity unearthed more doubts and riddles than definitive answers.

Jewish post-biblical midrashic texts, such as the Alphabet of Ben Sira or the Targum Sheni, insist on the queen's gender ambiguity (her hairy legs) and make explicit the possibility that she and Solomon had an intimate relation that led to a (dangerous) offspring: Nebuchadnezzar, who submits Israel to Babylon, is said to be their son. In later Christian commentary, the Queen of Sheba is assimilated to the Bride of Solomon's Songs and, in the Arabic versions based on the Coran (Sura of the Ants: 27, 22-44 and 34, 15-21), the nuptial theme is complemented with her troubling characterization as an ambiguous figure with demonic origins: now a pagan queen named Bilqîs, she is not only hairy but has an ass' foot or an eagle's claw (see fig. 3); Solomon,

\footnotetext{
1. There are some elements, though, that seem to point to an alternative interpretation: because the tests of legitimacy are so central in the narrative (see Spencer, 1978: 356-7), some researchers conceive that the authors-compilers of the Këbrä Nägäst, possibly church clerics from the holy city of Aksum, deliberately introduced a measure of veiled criticism (most probably in the spirit of the "wax and gold" or double-meaning literary method so praised in Ethiopian intellectual history) towards the recipients of the text: the Solomonid usurpers (see Grierson \& Munro-Hay, 2000: 272-4; Manfred Kropp in Hirsch \& FauvelleAymar, 2001: 66).
} 
who unveils her beastly nature, cures her, marries her and coverts her to the faith of Islam (Lassner, 1993: 87) ${ }^{1}$.

In both Semitic and in Indo-European literature, the Queen of Sheba has become a paradigm of feminine ambiguity, its frequently demonized characteristics $^{2}$ underscoring the questionable legitimacy of a concept of political power divided along gender lines.

As already mentioned, the stories about the Queen of Sheba are interlaced with those of the sacrifice of the legendary Arwe, in Ethiopia. The painted stories that can be found in many a souvenir shop or traditional painter's studio echo a rich and varied folklore only partially attached to the Këbrä Nägäst and the theological problems it poses ${ }^{3}$. Some legends make the connection between royal power and tyrannical monstrosity very explicit: the queen (Azeb) is the sister of Arwe. Other versions stress the notion of usurpation: Agabos poisons Arwe and subsequently grabs political power.

A particular characteristic of the Ethiopian painted stories is that, unlike most of their oral and written counterparts, they always introduce the figure of the black servant of the queen who systematically sleeps with Solomon before Makeda does (fig. 4). Also systematically, the painters clearly put a stress on the difference of skin colour: the servant is black, Makeda is red, and Solomon is white. But, when they portray Mënilëk and his half-brother, they both have red skin, and their face, posture and clothes are almost identical (fig. 5). Considering that the servant's son was conceived first and should thus have been destined to rule according to the principle of primogeniture, the painted stories use this sequence as an original way to stress the idea that Mënilëk is as much affected by a questionable legitimacy as any other power player of the story. In fact, whereas some visual elements of most paintings may be seen as simply anachronistic (Makeda eats from a masob or weaved table, Mënilëk is crowned in front of the stone stellae of Aksum), others demand a finer iconographic and historical analysis: a "lion of Judah" is represented next to the queen, not next to Solomon (fig. 6); the presence and meaning of the black servant and her son has to be read in the context of

1. The queen's claw bird claw resurfaces in a particular group of Ethiopian folk paintings: the portraits of Makeda and Solomon as bride and groom. In these paintings, where the influence of Arabic narrative sources is clearly visible, a bird's claw is laying on the ground, having fallen when the queen tripped over a wooden log from which, some Christian medieval sources say the true cross was later fashioned.

2. The Jewish rabbinical tradition has assimilated her to Lilith, the female demon. In European Christian folklore she appears as a savage and hairy woman, or born with a goose's foot.

3. The fact that Mënilëk is the first-born son of Solomon means that he becomes the rightful heir of King David's line. By removing the Ark from the Temple and taking it to Ethiopia, he and his Jewish companions ensure that Ethiopians will become God's elected people. The combination of this two aspects of the story produced a theological short-circuit with far reaching consequences: according to this view, Jesus Christ's ties with David's line are genealogically weakened, and the balance between the first and the second Covenant is reshaped by the Christian Ethiopian kings' claims to sacred legitimacy. 
deep political and cultural changes brought about in the whole territory since the reign of Mënilëk II, in the late $19^{\text {th }}$ century. ${ }^{1}$

There is a constant element of Angst throughout the Ethiopian narratives in that the protagonists' claims to political legitimacy are systematically questioned and tested: Agabos usurps Arwe's power, Sheba tests and is tested by Solomon, Mënilëk (who already owns the wisdom ring Solomon offered his mother) removes the Ark from the Temple and thus usurps the sacrality of his father's power. True to the perspective developed by many human societies that sacred kingly power - because it is sacred- is dangerous (Heusch, 1987: 291-2), the Abyssinian oral, written and painted literature about the Queen of Sheba has produced a consistent and rich web of meanings around the notion of ambiguous legitimacy.

1. Këdusse Giorgis slays the dragon. Painting by Hailu (oil on canvas, $115 \times 84 \mathrm{~cm}$, circa 1935). Col. Staatliches Museum für Volkerkunde, München.

2. Agabos slays Arwe with an empoisoned goat and is crowned king. Detail of a painted story of the Legend of Sheba and Solomon, by Jembere Hailu (oil on canvas, $133 \times 76 \mathrm{~cm}$, circa 1980). Private collection.

3. King Solomon greets Makeda, the Queen of Sheba, with a handshake over a lions skin, and a hoof falls from her foot. Painting by an unknown artist (oil on canvas, $86 \times 135 \mathrm{~cm}$, circa 1930). Col. Staatliches Museum für Volkerkunde, München.

4. Solomon sleeps with the servant and then with Makeda. Detail of a painted story of the Queen of Sheba (unknown artist, oil on goat's skin, $60 \times 112 \mathrm{~cm}$, circa 1990). Private collection.

5. Solomon welcomes Menelik, Makeda's son, and his half-brother, the son of the servant. Detail of a painted story of the Queen of Sheba (unknown artist, oil on cow's skin, $80 \times 110 \mathrm{~cm}$, circa 1980). Private collection.

6. Makeda, seconded by her servant and a lion, enters Solomon's palace. Detail of a painted story of the Queen of Sheba (unknown artist, oil on goat's skin, $60 \times 112 \mathrm{~cm}$, circa 1990). Private collection.

\section{BIBLIOGRAPHY}

BeYer R. 1987. Die Königin von Saba. Engel und Dämon. Der Mythos einer Frau. Bergisch Gladbach.

Da uм W. 1988. Die Königin von Saba. Kunst, Legende und Archäologie zwischen Morgenland und Abendland. Stuttgart; Zürich.

1. On the $19^{\text {th }}$ century renewal of the medieval legend, see Hirsch \& Fauvelle-Aymar, 2001: 65. 
Griaule M. 1930. "La légende illustrée de la reine de Saba" in Documents, $2^{e}$ année, no. 1, Paris, pp. 9-16.

Grierson R. \& S. Munro-Hay. 2000. The Ark of the Convenant. London.

Heusch L. de, 1982. Mythes et rites bantous II. Rois nés d'un caur de vache. Paris. -, 1987. Écrits sur la royauté sacrée. Bruxelles.

Hirsch B. \& F.-X. Fauvelle-Aymar. 2001. "Aksum après Aksum. Royauté, archéologie et herméneutique chrétienne de Ménélik II (r. 1865-1913) à Zär'a Ya'qob (r. 1434-1468)" in Annales d'Éthiopie, vol. XVII, pp. 59-109.

LASSNER J. 1993. Demonizing the Queen of Sheba. Boundaries of Gender and Culture in Postbiblical Judaism and Medieval Islam. Chicago; London.

Perret M. \& M. Denais. 1983. "La mort du serpent" in J. Tubiana (ed.) Guirlande pour Abba Jérôme. Travaux offerts à Abba Jérôme Gabra Musé par ses éléves et ses amis. Paris, pp. 117-52.

SPENCER M. 1979. "Structural Analysis and the Queen of Sheba" in Robert L. Hess. Proceedings of the Fifth International Conference on Ethiopian Studies - Session B (April 13-16, 1978, University of Illinois). Chicago, pp. 343-58.

Tubiana Joseph. 2001. "Introduction", Makeda, reine de Saba. Textes traduits par Hayla Maryam et Hugues Leroux (ed. Joseph Tubiana). Saint Maur, éditions Sépia.

UlLENDORF E. 1954. "Bilkis" in The Encyclopaedia of Islam, vol. 1, pp. 1219-20. 